\title{
Religious Movements in Humanitarian Issue: The Emergence of Faith-Based Organizations (FBO) in Diplomacy Sphere
}

\section{Fredy Munthe}

Center for Religious and Cross-cultural Studies, Gadjah Mada University

Bulaksumur, Yogyakarta 55281, Indonesia

fredy.torang@mail.ugm.ac.id

Submitted: 21 September 2016, Accepted: 14 Desember 2016

\begin{abstract}
Abstrak
Organisasi berbasis agama (FBO) memiliki peran yang kuat dalam melakukan diplomasi kemanusiaan. Namun, kuatnya peran yang dimiliki negarabangsa dalam lingkup diplomasi mengabaikan kemunculan FBO sebagai salah satu aktor. Sampai saat ini, belum ada teks yang secara eksplisit membahas munculnya FBO dalam diplomasi kemanusiaan. Semua teks hanya membahas masalah FBO dan aksi kemanusiaan. Namun faktanya, tidak ada bantuan kemanusiaan jika tidak ada diplomasi kemanusiaan sebelumnya. Oleh karena itu artikel ini mencoba untuk melacak munculnya FBO sebagai aktor diplomasi kemanusiaan. Artikel ini menganalisis perspektif diplomasi dan dampaknya terhadap kemunculan FBO sebagai aktor. Untuk melakukannya penulis menggunakan kajian literatur untuk mendapatkan data tentang hal tersebut. Artikel ini berguna untuk memperkuat posisi FBO sebagai salah satu aktor non-negara dalam ruang kemanusiaan begitu pula diplomasi.

Kata kunci: Diplomasi, Organisasi Berbasis Agama, Kemanusiaan, Aktor Non-negara
\end{abstract}

\begin{abstract}
Faith-Based Organization (FBO) has a strong role in conducting humanitarian Diplomacy. However, the strong role of the nation-state in that sphere ignored the emergence of FBO. Until now, there is no text that explicitly discusses the emergence of FBO in humanitarian diplomacy. All of the text only discusses the issue FBO and humanitarian action. In fact, there is no humanitarian aid if there is no humanitarian diplomacy previously. Therefore, this paper traces the emergence of FBO as the actor of humanitarian diplomacy. It analyzes the perspective of diplomacy and the impact of the emergence of $\mathrm{FBO}$ as the actor. This article use literature review to get data about the case given. This paper is useful for strengthening the position of $\mathrm{FBO}$ as the non-state actor in the humanitarian sphere as well as in diplomacy.

Keywords: Diplomacy, Faith-Based Organization, Humanitarian, Non-state Actor
\end{abstract}

\section{INTRODUCTION}

Faith-Based Organization (FBO) has a role in humanitarian diplomacy. Its presence brings a new spirit in seeking a form of humanitarian diplomacy. However, the strong role of the nation-state ignored the emergence of FBO in conducting humanitarian diplomacy. Most of the discussions only focus on the diplomacy which is conducted by nation-state for a humanitarian issue. Therefore this paper is presented to discuss the emergence of FBOs as the actor of diplomacy when they conduct a humanitarian activity for a livelihood of the refugees.

Some scholars have recognized the strength of FBOs in establishing relationships with many parties which allows them to collect support, including from government and other NGOs as well as other international parties who cooperate with this kind of organization (Ferris, 2011: 609-611). This phenomenon gives a description that $\mathrm{FBOs}$ also have a role in 
opening the access so the humanitarian aid can be distributed to the parties that need help (Minear $\&$ Smith, 2007: 53-54; Orji, 2011). The way of FBO in conducting negotiation with many parties is evidence that they also have ability as diplomats.

However, to date, there have been only three studies that mention FBO as one of the actors in the field of humanitarian diplomacy alongside the state and secular NGOs. In those studies there is no clear and comprehensive explanation how to perceive the emergence of the FBO as an actor in diplomacy for a humanitarian issue. Regnier (2011) only mentions that there are also humanitarian groups which engaged on the basis of faith while Minear and Smith (2007) added that those groups can be labelled as FBOs. In 2014, Kumesan tried to use the term of FBO and humanitarian diplomacy in her thesis. However, there is no explanation for the emergence of the $\mathrm{FBO}$ as the actor of diplomacy in a humanitarian sphere. Moreover, she only used the humanitarian diplomacy as a term that takes for granted. Until now, there are no detailed studies about the emergence of FBOs as the non-state actor in the field of humanitarian diplomacy.

Through this paper, the writer want to continue the research done by Minear and Smith, whose argumentation that $\mathrm{FBO}$ s are also playing a significant role as actors in humanitarian diplomacy (Minear \& Smith, 2007: 53-54). The writer wants to explain how FBO have emerged as the actors of humanitarian diplomacy in particular in supporting the livelihoods of refugees in several places. This paper aims to fill a scholarly gap between analysis of FBOs and about the concept of humanitarian diplomacy.

\section{ANALYSES}

Faith-Based Organizations (FBO) have taken on a major role in diplomacy as a response to the humanitarian issues. These indirectly force a paradigm shifting in naming the actors of diplomacy (Barston, 1997:

12). The diplomacy in the traditional conception placed states as the only actor to make decisions or even enter negotiations, but in recent times the conception has changed and shifted into a new one that is well known as the idea of multi-track diplomacy. It means that the actors are not only states but there are also many parties that can be considered as the actors. The multi-track diplomacy emerges because the state as the sole actor has limitations in responding to all humanitarian problems. Various actors have emerged in contributing to the response of those conditions, including FBOs, which, through their religious values, seek to aid the needy and vulnerable, including refugees. In the context of assistance, religious teachings have compatibility with existing humanitarian values. FBO uses religious language to communicate with sponsors and other stakeholders but also use the secular language in other contexts.

FBOs have presented since a few years ago and their existence has relevance with the number of humanitarian cases. In several impoverished regions, the role of FBOs is even more prominent than any secular groups (Ferris, 2011). Even though there are many critical questions about the rise of $\mathrm{FBO}$ in humanitarian work, it is a fact that FBO as one of the non-state actors with a role in international activities. It happens because they successfully make a connection through diplomacy.

In order to understand the involvement of FBOs in diplomacy for humanitarian purposes, this paper will highlight the development of diplomacy and the dynamics that influence the emergence of FBO. Furthermore, it will show how FBOs put the idea of faith into humanitarian issues. In the last part, this article will describe how FBOs work in some humanitarian cases through diplomacy.

\section{SHIFTING PERSPECTIVES ON THE ACTORS}

The shifting process in perceiving the actor of diplomacy occurs as the impact of the humanitarian issues. The development of humanitarian issues specifically leads to a shift of perspective to perceive the existence of diplomatic actor (Barston, 1997: 913). The shifting perspective provides a space for humanitarian workers who work for particular organizations to be perceived as diplomats, as well. 
Prior to the twentieth century, only the states used diplomacy to pursue their interests (Leguey-Feilleux, 2009: 23); (Black, 2010). There were many efforts from the states as the international actors to solve the humanitarian issues through diplomacy or round-table discussions. At that time, each of states cooperated with the others to gain benefits for their interests. This pattern was even legitimized in the Congress of Vienna in 1815. It led to the presence of diplomacy roles and to the respect of the legitimacy played by the state in International space (Lentner, 1997). The only actor that could play a role in international space was the nation-state. It means the title diplomat or envoy only referred to someone who had received the official mandate from a state to become a diplomat for other parties.

Recognizing the strong role of a state, Morgenthau (1972) then defined diplomacy as follows,

"the art of bringing the different elements of national power to bear with maximum effect upon those points in the international situation which concern the national interest most directly" (Morgenthau, 1972:146).

Morgenthau perceives the diplomacy as an effort of the international actors to get the interests. He emphasizes his perspective of diplomacy on the work of nation-state diplomats at a high level. The national interests that prioritize the domestic interest become the main priority that should be fulfilled by each state. Domestic demand emerges due to the need to resolve humanitarian problems within the borders of a particular state. A fulfilment of domestic demand in a particular state can be interpreted as the humanitarian activity which prefers to be prioritized by any actor when they want to make a link with outside parties. However, the humanitarian issue in this earlier understanding only refers to the activities limited by borders of a country. The humanitarian concern in this context does not reach beyond boundaries.

In addition, when perceiving the style of diplomacy carried out by state actors, so the existence of the diplomatic protocol cannot be avoided. The diplomatic protocol itself is a kind of guidance that must be followed. It is important because as Bull (1977) said, the diplomatic protocol becomes a bridge to communicate with the others (Bull, 1977:161). The diplomatic protocol itself has strict rules. All parties must have clear understanding about protocol and must commit to a long process before they exchange envoys. These requirements, in turn, became one of the barriers to the movement of the state actors in terms of reducing the humanitarian problems.

Even though the state has conducted a lot of effort to reduce the problems of humanity, in fact there were many humanitarian problems happened. As it is commonly known, a lot of conflicts happened, such as the Battle of Solferino, World War I and World War II, and the Vietnam War, as well as conflicts in Africa, Asia and also Latin America (Cahill, 2013:1720). Certainly, there were many people who became the victims due to these conflicts. Some of them had to be forcibly-displaced people as the impact of those conditions. They had to escape from their lands to seek a new place for continuing their life (Manning, 2005). Numbers of people became cross-border refugees as what happen to Rohingya people, refugees from East Timor, Syria, Iraq, Afghanistan and so forth.

Galtung (1969) and Tirtosudarmo (2015) argue that forcibly-displaced people existed because of the problem related to the security need of these people wish for (Galtung, 1969; Tirtosudarmo, 2015:281320). Even though the two scholars perceive this question of security from different perspectives, the essence of the problem is important for seeing the reality experienced by these people who are forcibly displaced and whose lives are threatened because of the condition. The state as the legitimated actor in the international context in fact fails to accomplish it.

The state as the only actor of diplomacy often ignores the existence and the needs of the forciblydisplaced people. If the state had taken a strategy in the form of diplomacy, so it would have only worked on the high-level politics. The state tends to limit its works only on that level. In order to handle the works of diplomacy in the field, the state often cannot make 
it. Seeing the condition, the existence of many state actors is not enough to provide humanitarian aid for the refugees. The state actor has limitations in accommodating the humanitarian needs through diplomatic means.

It is perceived that at least there are two limitations with recognizing the state as the one and only actor in diplomacy making response to the global humanitarian affairs. The first is the official protocol of the state. The limitation appears in the official protocol to decide a diplomacy strategy and along with the diplomat. This raises difficulties in realizing a rapid response to the global needs. International humanitarian world really needs the role of the parties that are able to go beyond it. The international humanitarian world needs an actor that can respond quickly toward the humanitarian problems that arise. It is very important because the refugees are the most vulnerable of people.

The second is the existence of the diplomat (representative). In the perspective of traditional diplomacy that puts the state as the only actor, only few parties are recognized as the diplomat. They are the people who get officially recognition from their country and also receiver country to become a representative (Bull, 1977:157). In fact, there are many humanitarian workers crossing the territorial boundaries, even though there is no recognition from their country or receiver country. The humanitarian workers even have to cross national borders to conduct negotiations with the others, so they can reach the refugees. Sometimes they even have to work among belligerents in order to reach the refugees. It is very difficult to do for an official state diplomat. This fact shows the condition that the humanitarian issues usually find a contradiction with the way of traditional diplomacy.

The presence of non-state actors become a bid to break the deadlock because of the state's limitation in responding to the international humanitarian issues through diplomatic ways (Leguey-Feilleux, 2009:105). The presence of non-state actors in the international political space has encouraged a change in the existing constellation of humanitarian issues (Manokha, 2011). The emergence of many humanitarian workers also gradually has shifted the rigidity of the existing rules related to diplomacy (Macalister-Smith, 1985:117). This moment gives an opportunity to other humanitarian organizations, especially those that are based on religious values to develop (Minear \& Smith, 2007:3637). Many non-state actors have emerged as the new power that also influence the international order (Black, 2010:224).

Perceiving this condition, in 1982, Joseph Montville introduced the Multi-Track Diplomacy concept to answer the phenomenon of the emergence of the other actors who did not officially work as state diplomats. In his text, Joseph Montville saw that there were many parties that could be recognized as a diplomat for their state when they had communication with other parties from another state. This phenomenon explains that there is a transformation of the diplomacy concept in international relations sphere. Joseph Montville perceived that the idea of diplomat did not only refer to nation-state diplomat (Diamond \& McDonald, 1996). There was a role of another actor that could act as the diplomat too. They could be non-governmental organizations (NGOs), multinational corporations (MNCs), churches and religious movements, transnational terrorists and revolutionaries, and private individuals (LegueyFeilleux, 2009:101-121).

There are many non-governmental organizations (NGOs) that have emerged as an impact of the humanitarian issues. Their presence on the international level is accordance with the number of international regulations that appeared (Simpson, 1945). It is known that the international regulations are made to provide respect to the humanitarian value. International Committee of Red Cross (ICRC) becomes one of the first organizations that take a concern on this issue. The existence of ICRC which was initiated by Henry Dunnant, becomes a stimulant for the development of humanitarian issues. Over the course of time, there are many parties involved in the humanitarian issues (Roeder \& Simard, 2013:3-4).

Multinational corporations (MNCs) are one of the international actors that appear as the impact of the 
condition change. The MNC itself is a businessoriented institution that has orientation on seeking a profit. Their expansions in international space have made them able to be actors that can affect local and international stability. The strong profit orientation of this actor is able to fill the weaknesses of the state in encouraging the economic condition of the countries.

Churches and religious movements are the international actors that emerge and fill the religious space. Leguey-Feilleux mentioned two actors as different institutions but their action was still in religious frame. They did so in order to accommodate the specific organizations based on their particular religious teachings. $\mathrm{FBO}$ is an example of such organizations. In the thesis written by Gres (2010) it was quite clearly stated that FBO was involved in international humanitarian activities (Gres, 2010). Such types of organizations grow and thrive in all countries to minimize the humanitarian issue including the impact of the wars (Cahill, 2013: 20).

Furthermore, transnational terrorist and revolutionary movements are another kind of non-state actors. They act as international actors because their existence often brings an impact upon the international level. The existence of such groups often gets support of funds from international actors. Generally, their main goal is to overthrow ruling governments. In general, their actions ignore humanitarian values.

Private actors are individuals who have the capability to make an impact in international scale through their thoughts or decisions. Leguey-Feilleux sees that the number of the actors is small, but the presence and their thoughts are influential on the international place. According to Leguey-Feilleux, they come from various places. They can be a former heads of particular institutions including businesses, governments and NGOs.

The shifting perspective in diplomacy studies has brought successfully a new perspective to perceive the diversity of the existing actors. The actors appear as the effect of the existing humanitarian issue. The limited ability of the state in fighting for humanitarian through global diplomatic agendas makes a number of non-state actors appear to help and provide solutions. The shifting process provides a starting point to discuss the potential role of FBOs in filling the gap that cannot be covered by state actors.

International humanitarian issues have become a trigger for the emergence of many FBOs. They are present as a form of response to a number of humanitarian issues at the global level (Wahid, 2007: 239251). The strength of the religious teachings has become a fundamental value in the works of FBO in humanitarian. From the observation of some scholars like Marshall (2005) and Ferris (2011), the existence of $\mathrm{FBO}$ is quite able to transform the religious teachings into the humanitarian work (Ferris, 2011). Certainly, there are many common values between religious teachings and humanitarian values that make the spirit of religious idea work in humanitarian activity. Starting from this point, this article will see the close relationship between faith values and humanitarian value.

\section{FBO: FAITH VALUES IN HUMANITARIAN ISSUES}

This part explains the common sense of the idea between faith value and humanitarian value of the FBO. It is important to discuss because through the faith value, the $\mathrm{FBO}$ can conduct the humanitarian activity. It means there must be a similarity between faith value and humanitarian value. To explain it clearly, some ideas that belong to certain religion which has similarity with the idea of humanitarian value will be explained. Furthermore this article will explain the idea of humanitarian and followed by the explaination of how the FBOs interpret the idea of humanitarian into the religious teachings.

The religious teachings share many ideas that are able to remind their adherents of how important it is to share with others. For instance, "the theme of justice for the poor, the marginalized and the alien is central to the Hebrew scriptures" (Ferris, 2005: 313). Furthermore, in Christianity there is the idea of loving your neighbors, like in Matthew 25: 35-40 and within Islam the idea of maintaining good relationships with all of humankind which is called hablumminannas. In 
addition, there is also a concept of Zakat in Islam which aims at helping other people. There are still many other ideas embedded in religious teachings about humanity. Certainly, those ideas are quite capable to shape the way the adherents think about how to treat each other and also the importance of sharing with others (Latief \& Mutaqin, 2015: 24-25).

Furthermore, concerning about the humanitarian concept, that can be sketchily concluded as the concept which puts the human as the center of the priority. Most scholars perceive that this concept was born from the concept of altruism and cosmopolitanism. Altruism itself is a concept introduced by August Comte (1798-1857). According to Krieg (2013)

altruism is defined as "describing a selfless and otheroriented behavior” (Krieg, 2013: 37). Krieg sees

altruism as a concept used to describe the characters of people who try to prioritize the needs of others rather than personal interests.

Hereafter, cosmopolitanism was born from the fruit of Immanuel Kant's ideas about universal virtue that crosses state boundaries. Some scholars believe that the value of cosmopolitanism can be used as a basis of thinking to solve humanitarian problems. According to Sugiono (2011) cosmopolitanism can be defined as follows,

...every single individual as a goal with ultimate value in itself and their existence is primary to any social organization. They cannot be treated as an instrument of social values or treated differently due to its artificial or social attributes such as citizenship. In more concrete terms, this means that an association of an individual with his or her country, as a citizen, should not qualify her or him to more or less rights or responsibility than other individuals of other countries. (Sugiono, 2011:224)

Certainly, those two values can be perceived as a guiding principle for the people to conduct humanitarian activity for others (Wispé, 1978:304).

Then, FBOs as the part of the certain religious groups also have a similar purpose in conducting the humanitarian activity. The work of FBOs for humanitarian activity is quite in accordance with cosmopoli- tanism idea. FBOs work in every sector of human life. Their existence is a part of the response to the humanitarian problems in society. Mostly the purpose of humanitarian workers is to save lives and to ameliorate suffering (Keishin, 2003). They design their vision and mission for keeping the humanitarian values. They start to put the public interest as their objectives.

The ability of FBOs in transforming the religious value into humanitarian action has become the strength of FBOs in real condition. This becomes an advantage for FBO because there are many people who sympathize with their work. One of them is the party who has the same religious identity with certain FBOs. As it is commonly known, there is always a tendency that the society will give donation to the parties that have similar identities with them. As the result, FBOs are more advantageous than the secular humanitarian groups (Minear \& Smith, 2007:36); (Latief \& Mutaqin, 2015). The alignments of FBO on humanitarian values through their religious teachings make them able to utilize all opportunities.

\section{THE WORK OF FBOS IN DIPLOMACY FOR HUMANITARIAN PURPOSES}

There are no explicit arguments from any scholars who assert about the role of FBO in humanitarian diplomacy. However, one thing which has to be realized by many parties is that humanitarian actions will not occur if there is no communication preceding it. The communication becomes a bridge idea of diplomacy to resolve the humanitarian issues. In order to get a depiction of FBO's work in humanitarian diplomacy space, a few problems of FBO in the field and the perception of how it deals with them will be elaborated in this part. To analyze this phenomenon, some examples from the issue of the forcibly-displaced people will be given. This is done because there are many movements conducted by $\mathrm{FBO}$ in regards to this issue. They have a massive movement to handle it (Fiddian-Qasmiyeh, 2011).

In Kenya 2007, there was a mass displacement because of the post-election violence between two big powers fighting to claim legitimacy (Parsitau, 2011). 
There were numerous people who became refugees because of this condition. The government lost control in handling the internally displaced-people, especially in fulfilling their needs for evacuation and during their stay in that place. There were many FBOs that emerged to solve the problem through humanitarian diplomacy. They sought to connect themselves to an international organization, the Kenyan Red Cross, some public authorities, local church, local government and so forth, for the common purpose of reducing their suffering of IDPs (Parsitau, 2011: 497).

Susanna Snyder also describes that there is a role of $\mathrm{FBO}$ in decreasing number of asylum seekers in the United Kingdom. In the past, the number of asylum seekers reaching the UK was quite big. At least in 2002, the number of asylum seekers reached 84,130. Certainly, it became a problem for the government. The emergence of FBO brought a success in decreasing this number (Snyder, 2011). There were many FBOs involved in that movement, such as Islamic Relief, Jewish Council for Racial Equality, Jewish Social Action Hub, etc. Their involvement in humanitarian diplomacy was clearly illustrated in the good relationship and communication with the government (Snyder, 2011). By connecting themselves to all parties, those FBOs created an image that the UK was a friendly state for the presence of asylum seekers (Snyder, 2011:572-573). They succeeded in changing people's attitude, and also government policy for standing on the humanitarian side. Finally, the involvement of many parties and government could help FBO and other humanitarian workers to fight for the rights of asylum seekers during their stay in the UK.

One concern that cannot be denied by the humanitarian workers is how to connect themselves with other parties. It is a kind of humanitarian diplomacy that must be conducted before they perform humanitarian activity. Orji (2011) also talks about it implicitly. He explains that the success obtained by FBOs in Nigeria is not only because of the FBO itself but also because of the connection with other parties. At that time, in Jos, Nigeria, there were FBOs from different faiths that established a cooperation with governments, national NGO, international parties and also local NGO (Orji, 2011: 487-488). Those FBOs succeeded in providing a relief to the people affected by the conflicts, particularly to those who became internally displaced-people.

A success story for FBOs can also be seen in Burma. It happened when the Karen Baptist convention was conducting humanitarian activity for the Karen societies. The Karen is one of the tribes that live in the borderland of Burma and Thailand. As like the Rohingya people, they also faced a nationalism issue. The governments of Burma and Thailand could not reach them because their location was quite isolated. The Karen Baptist Convention, however, could reach the Karen societies and provided assistance for them. In addition, Karen Baptist convention also built relationships through diplomacy with many parties especially from overseas (Horstmann, 2011).

In Australia, FBO even tries to influence the policy of the government. As it is commonly known, since a several years ago Australia has become a destination country for the refugees to seek a permanent place. At that time, FBOs in Australia could influence the government to give permission so that the asylum seekers could stay in Australia (Wilson, 2011).

...the faith-based hospitality that underpins the work of $\mathrm{FBOs}$ in the asylum sector has played a significant role in the substantial shifts in Australian government asylum policy in recent times, in particular the decision to expand the government's community detention program" (Wilson, 2011: 548).

Moreover, in the United States, the work of FBO in humanitarian diplomacy is successful because it has provided advocacy for the resettlement of the refugees; so that the refugees can have a place to stay in the USA. FBOs fight for it by providing assistance in conducting English classes, job skills training, and so forth. In addition, FBOs also conduct the humanitarian diplomacy with the society where the refugees live in, so that it could accept them (Eby et. al., 2011). FBO has flexibility in moving even into the grass roots 
level and conducting many creative movements.

This condition actually has provided a clear explanation that the role of FBO in humanitarian diplomacy can fill the gap that is left by the government. This is important to do because sometimes the positions of the refugees are quite difficult to reach. That matter is likely to happen as the impact of several problems, such as the lack of infrastructure, the conflict that keeps raging, or the limited access from the government. Humanitarian diplomacy aims to reach all refugees regardless of religion or place of origin and to provide assistance for them. It can be certainly done by many parties as long as they focus upon upholding the humanitarian value as the priority focus.

\section{CONCLUSION}

The existence of a diplomatic role of $\mathrm{FBO}$ requires the shifting perspective in the diplomacy studies. The shifting of perspective has occurred as the impact of the humanitarian cases and the involvement of nonstate actors. The shifting of perspective eventually provides a position for perceiving the non-state actors as the diplomat as well. The non-state actors emerge as a response to the state's limitations in fighting for the humanitarian issues through diplomatic ways. The limitations of the state can be seen from two aspects, such as the diplomatic protocol to design communication between each of the states and only a few parties that can be legitimized by the states as the diplomat. Those facts contradict with the needs of refugees in the field. The non-state humanitarian workers, in fact, have an ability to solve that matter.

One of the non-state actors is religious movement or some scholars recognized it as FBO. The religious teachings of FBOs have a similarity with the values in humanitarian diplomacy. In addition, the movement of FBO in assisting the refugees represents their ability to communicate their basic values and the purpose with all parties. The movement of FBO can be seen clearly in some countries. FBO can act as a humanitarian advocate for the needs of the refugee. They can act as diplomats, especially for those issues that cannot be addressed by the government.

\section{REFERENCES}

Barston, R. P. (1997). Modern Diplomacy. Edinburgh: Pearson Longman.

Black, J. (2010). A History of Diplomacy. London: Reaktion. Retrieved from http://public.eblib.com/choice/ publicfullrecord.aspx? $p=618746$

Bull, H. (1977). The anarchical society: a study of order in world politics. New York: Columbia University Press.

Cahill, K. M. (2013). History and hope: the international humanitarian reader. Retrieved from http://site.ebrary.com/id/10746730

Diamond, L., \& McDonald, J. W. (1996). Multi-track diplomacy: a systems approach to peace. West Hartford, Conn.: Kumarian Press.

Eby, J., Iverson, E., Smyers, J., \& Kekic, E. (2011). The Faith Community's Role in Refugee Resettlement in the United States. Journal of Refugee Studies, 24(3), 586-605.

Ferris, E. (2005). Faith-based and Secular Humanitarian Organizations. International Review of the Red Cross Revue Internationale de La Croix-Rouge $=$ International Review of the Red Cross, 87(858), 311-325.

Ferris, E. (2011). Faith and Humanitarianism: It's Complicated. Journal of Refugee Studies, 24(3), 606-625.

Fiddian-Qasmiyeh, E. (2011). Introduction: Faith-Based Humanitarianism in Contexts of Forced Displacement. Journal of Refugee Studies, 24(3), 429-439.

Galtung, J. (1969). Violence, Peace and Peace Research. Journal of Peace Research, 6, 170-171.

Gres, D. (2010). The Ambivalence of Religion within The Framework of Secular Humanism the Case of Faith-Based Humanitarian Organizations. University of British Columbia. Retrieved from http:// hdl.handle.net/2429/19235

Horstmann, A. (2011). Ethical Dilemmas and Identifications of FaithBased Humanitarian Organizations in the Karen Refugee Crisis. Journal of Refugee Studies, 24(3), 513-532.

Krieg, A. (2013). Motivations for Humanitarian Intervention Theoretical and Empirical Considerations. Dordrecht; New York: Springer. Retrieved from http://dx.doi.org/10.1007/978-94-007-5374-7

Latief, H., \& Mutaqin, Z. Z. (2015). Islam dan Urusan Kemanusiaan: Konflik, Perdamaian, dan Filantropi. Jakarta: Serambi Ilmu Semesta.

Leguey-Feilleux, J.-R. (2009). The Dynamics of Diplomacy. Boulder: Lynne Rienner Publishers.

Lentner, H. H. (1997). International politics: theory and practice. Minneapolis/St. Paul: West Pub. Co.

Macalister-Smith, P. (1985). International Humanitarian Assistance: Disaster Relief Actions in International Law and Organization. Dordrecht; Boston; Hingham, MA, USA: M. Nijhoff/ ; Distributors for the U.S. and Canada, Kluwer Academic Publishers.

Manning, P. (2005). Migration in World History. New York: Routledge. Minear, L. \& Smith, H. (2007). Humanitarian Diplomacy Practitioners and Their Craft. Tokyo; New York: United Nations University Press. Retrieved from http://search.ebscohost.com/ login.aspx?direct=true\&scope =site\&db=nlebk\&db=nlabk\&AN=217489

Morgenthau, H. J. (1972). Politics among Nations: the Struggle for Power and Peace. 5th edition. Hans J. Morgenthau. New York: 
A.A. Knopf.

Orji, N. (2011). Faith-Based Aid to People Affected by Conflict in Jos, Nigeria: An Analysis of the Role of Christian and Muslim Organizations. Journal of Refugee Studies, 24(3), 473-492.

Parsitau, D. S. (2011). The Role of Faith and Faith-Based Organizations among Internally Displaced Persons in Kenya. Journal of Refugee Studies, 24(3), 493-512.

Régnier, P. (2011). The Emerging Concept of Humanitarian Diplomacy: Identification of A Community of Practice and Prospects for International Recognition. International Review of the Red Cross, 93(884), 1211-1237. http://doi.org/10.1017/ S1816383112000574

Roeder, L. W., \& Simard, A. J. (2013). Diplomacy and Negotiation for Humanitarian NGOs. New York, NY: Springer. Retrieved from http:/ /dx.doi.org/10.1007/978-1-4614-7113-4

Simpson, S. (1945). International Organization in the Area of Social and Humanitarian Problems. Social Service Review, 19(1), 1-23.

Snyder, S. (2011). Un/settling Angels: Faith-Based Organizations and Asylum-Seeking in the UK 1. Journal of Refugee Studies, 24(3), 565-585.

Sugiono, M. (2011). Cosmopolitanism and World Politics: Bringing the Global World to International Relations. SSRN. Retrieved from http://papers.ssrn.com/abstract $=2001953$

Tirtosudarmo, R. (2015). On The Politics of Migration: Indonesia and Beyond. Jakarta: LIPI Press.

Wahid, A. (2007). Islam Kosmopolitan: Nilai-Nilai Indonesia \& Transformasi Kebudayaan. Jakarta: Wahid Institute.

Wilson, E. (2011). Much to be Proud of, Much to be Done: Faithbased Organizations and the Politics of Asylum in Australia. Journal of Refugee Studies, 24(3), 548-564.

Wispé, L. (1978). Altruism, sympathy, and Helping: Psychological and Sociological Principles. New York: Academic Press.

稲場 圭信, イナバ ケイシン, \& Inaba Keishin. (2003). Meaning and Construction of Altruism in New Religious Movements. 人間科学研究 / 神戸大学発達科学部人間科学研究センター 編... 11(1), 1-15. 